\title{
Police conduct toward complainants of crime: Cross-sectional study of Punjab Police
}

\author{
Perilaku polisi terhadap pengaduan pidana: Studi lintas sectional \\ Kepolisian Punjab
}

\author{
Zaheer Abbas', Muhammad Babar Akram ${ }^{1}$, \& Muhammad Saud ${ }^{2 *}$ \\ ${ }^{1}$ Department of Sociology, Faculty of Social Sciences, International Islamic University \\ ${ }^{2}$ Department of Sociology, Faculty of Social and Political Sciences, Universitas Airlangga \\ Address: ${ }^{1}$ Sector H-10, Block A New Campus, Islamabad, Pakistan 44000 \\ ${ }^{2}$ Jalan Dharmawangsa Dalam, Airlangga, Surabaya, East Java, Indonesia 60286 \\ E-mail: muhhammad.saud@gmail.com
}

\begin{abstract}
The continual debate about the purpose, role, and function of the police for making the well-known organization is of keen interest for scholars. The present study aimed to explore the role of police conduct and its relationship with the complainants of crime in Pakistan's geographical area. The study utilized a quantitative research design to gather data from the field. A research instrument prepared to collect the data from respondents who have ever interacted with the police. The sample size of 385 respondents selected for the known population and multistage and proportionate random sampling techniques were applied to draw the sample. The study was limited to Gujrat District in Punjab Province, and respondents selected through this universe. The study revealed significant barriers that restrict the police department's efficiency and gain public trust in them. Theoretically, it was beneficial for elevating Pakistani criminology on the subject and practice; the research provides insights for taking the appropriate measures for better police-public liaison. The study's findings revealed that the complainants generally agreed that they have limited trust in the police and that political interference is one of the major causes of lack of public trust.
\end{abstract}

Keywords: Punjab Police; complainants; police efficiency; political reference; cross-sectional study

\begin{abstract}
Abstrak
Perdebatan berkelanjutan tentang tujuan, peran, dan fungsi kepolisian untuk menjadi suatu organisasi yang ternama merupakan objek ketertarikan tersendiri di kalangan akademisi. Penelitian kali ini bertujuan untuk mengeksplorasi peran perilaku polisi dan hubungannya dengan pelapor kejahatan di wilayah geografis Pakistan. Penelitian ini merupakan penelitian kuantitatif yang dirancang untuk mengumpulkan data dari lapangan melalui para responden yang pernah berinteraksi dengan polisi. Ukuran sampel sebesar 385 responden dipilih dari populasi melalui teknik pengambilan sampel acak bertingkat dan proporsional. Penelitian ini terbatas pada Distrik Gujrat di Provinsi Punjab; responden dipilih dalam batasan ini. Penelitian ini mengungkap hambatan signifikan yang membatasi efisiensi satuan kepolisian dan bagaimana kepolisian mendapatkan kepercayaan publik. Secara teoretis, temuan ini bermanfaat untuk mengembangkan kajian kriminologi di Pakistan mengenai subjek dan praktik tersebut. Penelitian ini juga menyediakan wawasan untuk menerapkan langkah-langkah yang tepat guna meningkatkan hubungan antara polisi dan masyarakat. Lebih lanjut, temuan penelitian ini mengungkapkan bahwa pelapor kejahatan umumnya setuju bahwa mereka memiliki kepercayaan yang terbatas pada polisi, dan bahwa campur tangan politik terhadap satuan kepolisian merupakan salah satu penyebab utama kurangnya kepercayaan publik tersebut.
\end{abstract}

Kata kunci: Polisi Punjab; pelapor; efisiensi kepolisian; referensi politik; penelitian lintas-seksi

\section{Introduction}

The construction of police images has a strong linkage with police personnel's performance because of the public. An effective relationship between public and police is a key indicator of police performance, which ultimately helps to tackle crime in society (Frantzen 2010). Public trust in police is built on the grounds of their effective performance and for the improvement of public trust in society. Globally, the police are considered to be caretakers of public safety needs (Albrecht 2017). There exists a substantial nexus between public trust and police conduct. Therefore, modern 
societies tend to build a functional relationship between these two parties. The main argument of the present study is interested to see the importance of police conduct for gaining public trust in them. It is assumed that such liaison plays an essential role in bringing social conformity in society. The effective relationship between the two parties is essential for social order and public perception to maintain the police's excellent character. Similarly, Packman (2010) defined police misconduct as any action performed by a law enforcement officer that is unethical, against established employment guidelines, unconstitutional, or criminal. He further explained that police misconduct is the abuse of police authority. Sometimes police misconduct is used interchangeably, and this term refers to a wide range of procedural, criminal, and civil violations.

The term 'procedural misconduct' is a kind of misconduct in which police personnel violates departmental rules and regulation. Such kind of misconduct occurs during duty hours. Weitzer and Tuch (2002) explain that there are four types of police misconduct in the procedural process, verbal abuse, excessive force, unwarranted stop, and corruption. It is also found that procedural misconduct is started when a person goes to the police station to report a case against someone, and this is the start of the legal process. As per law and procedural ethics, police officers should provide the person a comfortable environment before starting the procedure, for instance, 'say welcome', 'provide security', 'ensure for justice', 'follow up the case honestly' and other gestures to make a conducive environment in the process.

After the procedural misconduct, there is another, 'civil rights misconduct', which points out that police officers violate citizens' civil rights. There are many departmental policies and guidelines are written specifically to address potential breaches of constitutional protections or legal guidelines, but some may not meet the given criteria. Civil rights in every society have a fundamental status that cannot be breached by anyone. Sexual harassment cases are often victims of such civil misconduct (Gold 2018). The third is criminal misconduct, which holds that the police officer who violates the state and federal laws is guilty of such misconduct. Furthermore, criminal misconduct is the use of police resources for personal use, security breaches, and profane language (O'Connor 2005). Crime is defined as the violation of written rules and regulations set by the state. Excessive use of force is usually seen in civil and procedural processes. Criminal misconduct includes assault, battery, theft, and false arrest.

The present study was conducted in the province of Punjab, which is situated in the center and is the biggest area of Pakistan. It contributes to approximately $56 \%$ of the total economy of Pakistan. In Punjab, the police department was established in 1905, with Sir Edward French as its first Deputy Superintendent General (DSG). There were assets associated with using those individuals to research illegal doings, including fingerprints and lawful laboratories (Aulakh \& Khan 2005). It is to conclude that the police are contributing to the general public in any area of the community (Abubakar et al. 2017). The important factor in policing is 'trust', which recommends the significance and perception of stable certification regarding difficulty to the individuals or groups, which has regarded after a while or in any conditions. Trust makes a supposition of protection or unfettered from terror; the goal can straightforwardly focus on extraordinary issues of life. Stoudt et al. (2019) found that in our society, people can register complaints, while complainant consideration is an urgent goal of any police officer to maintain trust and respect in society. Therefore, the performance of police has been featured as a regulatory limit (De Schutter 2019). Sanders \& Langan (2019) articulated that the police association needs to understand public affectability and underwriting and not promote estrangement

Alvi (2011) offered an exhaustive examination of Pakistani police in that the image of the police in Pakistan is very devalued condition on account of oblivious, unlettered officials, not recommended planning, nonappearance of principal community offices in the police stations, and political load on the police officials which has driven toward a structure of negative residents' acknowledgment about the police. The primary objective of the police is to hold the public's trust, which creates opportunities to maintain trust in public affairs. For instance, their level of trust shows their confidence in the limit of the police to ensure their security in the given conditions (Ullah \& Ibrar 2019). Police are afforded a great deal of official capacity to control the law and enforcement situation in the community. This gives prestige and respect in society, with a similar example that can be added to the current context is 
that progressing investigations in China point to a positive association among age factors and trust in the police (Lai 2010). Regarding the impacts of citizens' trust in the police, in particular, the creators tried to clarify why a few people distrust the police and others. It considered public attitude toward the police under the course of the nature of protestations about them. Therefore, the age factor is also essential to maintain a spirit of trust among the public (Akram et al. 2018, Tankebe \& Asif 2016).

As of late, a neo-Durkheimian model claimed that the fear of crime does not explain trust in police and assessment of police for their safety but rather by citizens' conviction that their neighborhood is morally degenerative (Jackson \& Sunshine 2007). In addition, scholars (Bradford et al. 2009, Khan \& Khan 2017) have suggested that occupants' assessment of police execution is started by and established in their appraisals of the social peace, trust, and good agreement of their neighborhood. It also adds that the dimension of rank, proficient experience and unit task were profoundly appropriate to officers' attitudes toward citizens (Paoline et al. 2000). It also highlighted that the network policing model argues the police to support inhabitant interest in public security programs through socioeconomic status and the subject's attitude toward the police (Waseem 2019 \& Wu et al. 2009).

The main argument of the present study is to highlight police misconduct and public distrust in the Punjab police. This study tries to analyze the primary factors behind the different levels of misconduct, which are criminal, procedural, and civil rights. It also gives a broader opinion on the role of publicpolice trust in the police department of Punjab. Police performance and public level of trust in police have captured the attention of social scientists. There is a rising concern among them to explore public judgment about police performance and public trust in the police and, specific researches have been widely conducted in the field of sociology and criminal justice for the dimension of public opinion in this regard. The significant highlights will be essential to make some standard procedures (SOPs) for the police department in the Punjab province.

\section{Research Method}

The present study opted for the quantitative survey research design to collect from complainants who visited the police stations during 2016. Official permission to gather the data was availed from the respective departments of the Punjab Police and International Islamic University, Pakistan. The respondents' detailed data were available in the First Investigation Report (FIR) paper that used to access the complainant data for the said study. A total number of four police stations were visited; City Circle Police Station, Sadar Police Station, Dinga Police Station, and Cantt Police Station situated in Kharian, District Gujrat, Pakistan.

The primary data collected a sample of 385 respondents using a proportionate sampling technique. The category of the sample includes male and female gender (complainants) who visited the above police stations. The data collection procedure gained from a self-administered questionnaire, which took sufficient time to compile the data from each respondent - the responses we re-analyzed using statistical mean and standard deviation for each response category. The data were categorized and analyzed through SPSS- V25, which used to analyze mean, standards deviation, and correlation test for dependent and independent variables. The dataset of this research has been prepared carefully by considering IV and DV measures (Abbas et al. 2020). The data also presented in a tabulated and figure form, which gives the perfect picture of quantitative data for easy analysis and description.

\section{Results and Discussions}

The respondents' demographic or socioeconomic variable plays a significant role in analyzing or evaluating the results from data. The table shows the demographic profile, gender, age, and education. The primary data sources presented in Table 1 show that most of the complainants were male $(82.6 \%)$, and the age category was 35-45 years. Education plays a significant role in the learning and outcomes of the objective, which can support and build the capacity as democratic citizens (Aman et al. 2019, Saud et al. 2020). It can be seen in Table 1 that more than half of the respondents (58.7\%) had matriculation level education, which indicates that the higher number was educated and had the knowledge to register their complaints in the period of 2016. 
Table 1.

\begin{tabular}{lcc}
\multicolumn{2}{c}{ Demographic variables of the study $(\mathrm{n}=385)$} \\
\hline \multicolumn{1}{c}{ Variables } & Frequency & Percent $(\%)$ \\
\hline Gender variables & 318 & 82.6 \\
Male & 67 & 17.4 \\
Female & & \\
Age category & 106 & 27.6 \\
24-34 years & 174 & 37.1 \\
35-45 years & 105 & 35.3 \\
46-56 years & & \\
Education qualification & 40 & 10.4 \\
Illiterate & 90 & 23.4 \\
Primary & 226 & 58.7 \\
Matriculation & 29 & 7.5 \\
Graduation & Source: Primary survey \\
\hline
\end{tabular}

Table 2 shows the descriptive findings of police behavior during the procedural process at the police station. Procedural misconduct is part of the independent variable in the present study. Three items measured this variable, i.e., police investigate the complainants based on socioeconomic status in the community; investigating officer asks to nominate suspects for the investigation, and the investigating officer did not work on the complaints without any reference. For the first item, police investigate the complainants based on socioeconomic status in the community, primary data show that a considerable majority of $79.5 \%$ of the complainants shared that police investigated the complainants based on socioeconomic status in the community.

In Table 2, around a quarter, $73 \%$ of the population strongly agreed to investigate the officer asking to nominate suspects for investigation. This higher value indicates that the investigating officer asked the respondents to file a doubtful person for this case. The third variable explained that police officers did not care about the complainants if they did not have any references. These statistics showed that, without political or any other strong reference, police officers did not properly work on the registration of the case. Table 2 shows $74.5 \%$ actively reported that the police did not look after the complainants without any reference. The results of this table explain that, if the complainants have strong politically or reference-based relations in the constituency, then they can easily file a case.

Table 3 portrays the descriptive details of police civil rights-based misconduct. Three items measured this variable: police officers verbally torture offenders, police officials are not aware of fundamental human rights, and police officers use official vehicles for personal use. The first statements indicate that more than half $(52.5 \%)$ strongly agreed that police personnel torture offenders verbally. Further results show that more than $90 \%$ of the complainants agreed that police officials abuse the offenders verbally. In Table 3, the second statement findings revealed that just over half (53.2\%) agreed that police officials deal with the complainants inhumanely. The second majority (44.2\%) strongly agreed that police did not regard the fundamental civil rights of the complainants at the time of dealing with them. Moreover, the findings showed that a considerable majority (77.4\%) shared that police officials used departmental vehicles for personal use. They used the police vans for their family and other work besides departmental.

Table 4 depicts the correlation matrix of the dependent variables; according to the findings, there is a relationship between the variables. Investigational misconduct results show the correlation between the two variables, and this variable has an association with police procedural distrust. Police investigational process is linked with police procedural distrust. The survey data of the table illustrate that the investigational police misconduct had a statistically significant and positive $(r=0.277$, 
$\mathrm{p}<0.01)$ relationship with police procedural distrust. Moreover, it is found that police officers did not perform their duties professionally, and the reported correlation coefficient between investigational misconduct and police outcome-based distrust $(\mathrm{r}=0.152, \mathrm{p}<0.01)$ represents a significant and positive relationship. The research expresses that the investigational police process is not satisfactory for the respondents. The results suggest that complainants had no confidence in investigational police conduct with procedural processes and outcomes. The results of the following research show that police criminal misconduct significantly correlated with procedural distrust $(\mathrm{r}=0.344, \mathrm{p}<0.01)$. The results also depict that criminal misconduct and outcome-based distrust had a statistically positive and significant relationship $(\mathrm{r}=0.315, \mathrm{p}<0.01)$.

Table 2.

Police behavior during the procedural process at the police station $(n=385)$

\begin{tabular}{lcc} 
& Frequency & Percent (\%) \\
\hline Police investigate the complainants based on socioeconomic status in the community \\
Disagree & 21 & 5.5 \\
No opinion & 3 & 0.8 \\
Agree & 55 & 14.3 \\
Strongly Agree & 306 & 79.5 \\
Investigating officer asks you to nominate suspect for investigation & \\
Disagree & 19 & 4.9 \\
No opinion & 9 & 2.3 \\
Agree & 76 & 19.7 \\
Strongly Agree & 281 & 73 \\
Investigating officer did not work on the complaint without any & reference & \\
Disagree & 14 & 3.6 \\
No opinion & 2 & 0.5 \\
Agree & 82 & 21.3 \\
Strongly Agree & 287 & 74.5 \\
\hline Total & 385 & $\mathbf{1 0 0}$ \\
\hline
\end{tabular}

Table 3.

Police civil rights and misconduct $(n=385)$

\begin{tabular}{lcccc}
\hline \multicolumn{1}{c}{ Variables } & Disagree & $\begin{array}{c}\text { No } \\
\text { opinion }\end{array}$ & Agree & $\begin{array}{c}\text { Strongly } \\
\text { agree }\end{array}$ \\
\hline Police officials torture offenders verbally & 21 & 4 & 158 & 202 \\
& $(5.5 \%)$ & $(1 \%)$ & $(41 \%)$ & $(52.5 \%)$ \\
Police officials are not aware of basic human rights & 8 & 2 & 205 & 170 \\
& $(2.1 \%)$ & $(0.5 \%)$ & $(53.2 \%)$ & $(44.2 \%)$ \\
Police officers utilize official vehicle for personal use & 4 & 34 & 4 & 298 \\
& $(1 \%)$ & $(8.8 \%)$ & $(1 \%)$ & $(77.4 \%)$ \\
\hline
\end{tabular}

Source: Primary survey

Every human being has the right to live in society according to basic human rights. The police department is considered one of those that protect civilians' basic human rights. It is observed that police attitude is not cooperative with the complainants while registering the cases. According to law, every citizen has equal rights for survival in society. The table portrays that respondents' civil rights misconduct was significantly correlated with police procedural distrust $(\mathrm{r}=0.251, \mathrm{p}<0.01)$. Also, results show that there is not a significant relationship among the variables of civil rights misconduct and outcome-based distrust $(\mathrm{r}=0.237, \mathrm{p}<0.01)$. Police behavior with the public is an important aspect behind public trust in police. The complainants reported that police behavior is not friendly and well- 
mannered while visiting police stations. The findings illustrate that police behavior was statistically significant and positively associated with the variable police procedural distrust $(r=0.161, p<0.01)$ and outcome based distrust $(\mathrm{r}=0.315, \mathrm{p}<0.01)$. The results of the last item of the Table 4 show that police misconduct while filing the complaints (FIR) significantly correlated with procedural distrust $(\mathrm{r}=0.143, \mathrm{p}<0.01)$. The results also portray that misconduct while filing the case, and outcome based distrust had a statistically positive and significant relationship $(\mathrm{r}=0.282, \mathrm{p}<0.01)$.

Table 4.

Correlation matrix of independent variables

\begin{tabular}{lcc}
\hline & Procedural distrust & Outcome-based distrust \\
\hline Investigational misconducts & $.277^{* *}$ & $.152^{* *}$ \\
Criminal misconducts & $.344^{* *}$ & $.315^{* *}$ \\
Civil rights misconducts & $.251^{* *}$ & $.237^{* *}$ \\
Police behaviour & $.161^{* *}$ & $.315^{* *}$ \\
Misconduct in filling a complaint (FIR) & $.143^{* *}$ & $.282^{* *}$ \\
${ }^{* *}$ Correlation is significant at the 0.01 level (2-tailed) & \\
\hline \multicolumn{3}{c}{ Source: Primary survey }
\end{tabular}

\section{Conclusion}

The results of the current research found that the assessment of public opinion about police performances and public trust in the police play a vital role in enhancing police competence. The common man may face unconceivable complications in looking for justice throughout his life. He may knock at different doors in search of justice, but, by the dryness of fortune, all his hard work in this regard finishes in smoke. The respondents were strongly agreed that political interference is one of the major causes of the lack of public trust in police. The relation of the police to the general people was not considered satisfactory in most ways. The significant relationship between police trust and the public shows the actual performance of the police. The police behavior with the public is an important aspect behind the public trust in police. The complainants of the present study accused that police behavior is not friendly and well-mannered while visiting the police stations. These practices are spread to give shelter to the worst kinds of people, such as drug mafia or criminals. In the last, it was understood that police behaviors are not respectful and welcoming to the people they interrogate and they carry out their procedures with little professionalism, thus there is a general public hatred them and people try to refrain from being involved in any situation linked to the police in any way.

\section{Acknowledgment}

The primary data of this study was collected purely for the purpose of a Ph.D. degree on the topic of "Police misconduct and public distrust: A cross-sectional study of district Gujrat, Pakistan" (23-FSS/ PHDSOC-F15). Author (s) would like to acknowledge all the stakeholders of this study.

\section{References}

Abbas A, Eliyana A, Ekowati D, Saud M, Raza A, \& Wardani R (2020) Data set on coping strategies in the digital age: The role of psychological well-being and social capital among university students in Java Timor, Surabaya, Indonesia. Data in Brief 30:105583. https://doi.org/10.1016/ j.dib.2020.105583.

Abubakar DS, Othman ZB, \& Mustaffa JB (2017) Community policing participation intention and the indirect effect of attitudes toward the police: A proposed model. International Journal of Management Research and Reviews 7 (3):225-236.

Akram MB, Bhutto NA, \& Mahmood QK (2018) Job satisfaction among police officers in District Rawalpindi, Pakistan: Role of demographic, social and psychological factors. Journal of Grassroots 52 (1):188-199.

Albrecht JF (2017) Analyzing the application of competing theories of justice into American and Pakistani policing strategies. Pakistan Journal of Criminology 9 (3):1-23. 
Alvi HA (2011) Winning Hearts and Minds: The "Rastoon" Deradicalization Program in Swat. Cambridge: John F. Kennedy School of Government.

Aman J, Akram MB, Mas'udah S, Saud M, \& Manj YN (2019) Parental involvement for better education: The relationship between parental awareness, emotional support, and children's academic achievement at secondary level. Masyarakat, Kebudayaan dan Politik 32 (4):334345. http://doi.org/10.20473/mkp.V32I42019.334-345.

Aulakh AMA \& Khan RAR (2005) Crime \& Criminology: A Comparative Study in the Context of Islamic Republic of Pakistan. Rawalpindi: Federal Law House.

Bradford B, Jackson J, \& Stanko EA (2009) Contact and confidence: Revisiting the impact of public encounters with the police. Policing \& society 19 (1):20-46. https://doi.org/10.1080/ 10439460802457594.

De Schutter O (2019) International Human Rights Law. London: Cambridge University Press.

Frantzen D (2010) Canine sniffs and policing the drug war. Criminal Justice Review 35 (4):438-452. https://doi.org/10.1177/0734016810363785.

Gold F (2018) Investigating and Prosecuting Law Enforcement Sexual Misconduct Cases. United States Attorneys' Bulletin 66:77-92.

Jackson J \& Sunshine J (2007) Public confidence in policing: A neo-Durkheimian perspective. British Journal of Criminology 47 (2):214-233. https://doi.org/10.1093/bjc/azl031.

Khan N \& Khan S (2017) An analysis of policing and problems existing in policing of Pakistan: A content analysis approach. Journal of Sociology 1 (1):54-65.

Lai RY (2010) System and method for generating web service architecture using web services structured methodology. United States Patent No. 7,698,398.

O'Connor DJ (2005) Integrating human behavior factors into design: An examination of behaviors that increase or reduce harm from fires. Fire Protection Engineering 28:8-20.

Packman D (2010) National Police Misconduct Reporting System. Washington DC: Cato Institute.

Paoline III EA, Myers SM, \& Worden RE (2000) Police culture, individualism, and community policing: Evidence from two police departments. Justice Quarterly 17 (3):575-605. https:// doi.org/10.1080/07418820000094671.

Sanders CB \& Langan D (2019) New public management and the extension of police control: community safety and security networks in Canada. Policing and Society 29 (5):566-578. https://doi.org/10.1080/10439463.2018.1427744.

Saud M, Ida R, \& Mashud M (2020) Democratic practices and youth in political participation: A doctoral study. International Journal of Adolescence and Youth 25 (1):800-808. https://doi.or $\mathrm{g} / 10.1080 / 02673843.2020 .1746676$.

Stoudt BG, Torre ME, Bartley P, Bissel E, Bracy F, Caldwell H, \& Lizama S (2019) Researching at the community-university borderlands: Using public science to study policing in the South Bronx. Education Policy Analysis Archives 27 (56):3-41. https://doi.org/10.14507/ epaa.27.2623.

Tankebe J \& Asif M (2016) Police legitimacy and support for vigilante violence in Pakistan. International Journal of Comparative and Applied Criminal Justice 40 (4):343-362. https:// doi.org/10.1080/01924036.2016.1217425.

Ullah F \& Ibrar M (2019) Effectiveness of police public services mechanism in crime reduction in Khyber Pakhtunkhwa, Pakistan. Pakistan Journal of Criminology 11 (1):131-140.

Waseem Z (2019) 'Brothers in arms'? A police-paramilitary partnership in Karachi. Policing and Society 1-17. https://doi.org/10.1080/10439463.2019.1705824.

Weitzer R \& Tuch S (2002) Perception of racial profiling: Race, class, and personal experience. Criminology 40 (2):435-56. https://doi.org/10.1111/j.1745-9125.2002.tb00962.x.

Wu Y, Sun I, \& Triplett R (2009) Race, class or neighborhood context: Which matters more in measuring satisfaction with police?. Justice Quarterly 26 (1):125-156. https://doi. org/10.1080/07418820802119950. 